\title{
The main problems and Countermeasures of freight transportation in modern enterprises
}

\author{
Yu Xia \\ Guangdong University of Science \& Technology, Dongguan 523083, China
}

Keywords: freight transportation; railway; countermeasure; government; logistics

\begin{abstract}
With the development of China's market economy and the adjustment of economic structure, the cargo transport market share is more and more important in the fierce market competition environment, so it expands the freight transport logistics market to obtain new business growth and development has become an inevitable trend. In the new situation, how to develop modern logistics is a new subject for the traditional freight transportation industry. If the transformation of transportation enterprises is going to implement the existing traditional transportation enterprise to modern logistics enterprise, the most important is the introduction of the concept of modern logistics. The necessity and feasibility of deeply understanding the railway transport enterprise can develop modern logistics to business leaders and employees from a combination of theory and practice so as to correctly determine the market positioning for the development of modern logistics enterprises. On this basis, transportation enterprises can scientifically formulate their long-term strategic planning.
\end{abstract}

\section{Introduction}

In the face of the population of the passenger transport market, railway, highway and aviation passenger are faced with the increasingly fierce competition.According to the analysis of Chinese status of railway passenger transport,if railway passenger transport wants to increase income and achieve stable development, it must develop the market of short distance passenger transport. With the development of many kinds of economy and the adjustment of economic structure, industrial structure,product structure and the market demand of freight transportation have changed greatly. First of all, the transportation service object has changed greatly. The common development of various economic forms in the socialist market has brought about changes in the object of railway transportation service.The number two is that the freight transportation category structure has had the very big change. With the development of high-tech industry, multi category, small batch, high value-added goods also have had rapid growth. Three, because of the fierce competition of various modes of transportation, the owner's choice of transportation mode is becoming larger and larger, and the quality of transportation service is getting higher and higher.

\section{The present situation of freight transportation in modern enterprises}

China's railway transportation industry has been 127 years old. Compared with the high-tech industries,it is a traditional industry such as computers, communications,biology and so on. In twenty-first Century, the world railway transportation industry is changing from traditional industry to modern industry. The developed countries in the world have completed the upgrade from traditional industries to modern industries in a new way with a shorter period of time. The railway industry has taken on a completely new look as a traditional industry. The construction of China's 
railway transportation industry is not very late.But compared with the developed countries, the gap is great, and there are still many problems.

In the last century in 90s, huge cargo needs of the whole society to break out of the pressure to the railway transport.An important raw material for national economic development need oil, cotton, grain, coal, ore and other serious disruption, which can increase the power supply gap of the eastern region and force many factories running semi shutdown. The lack of railway development has caused great losses to the country. At the same time,the overall tension in passenger transport has become a serious social problem.

\section{The main problems of modern enterprise cargo transportation}

In the past more than and 60 years, China's railway transportation industry is developing rapidly, but in recent years, along with the market economy reform further and the development of the national economy growth, railway transportation industry appears a lot of problems. These problems are focus on the overall scale of railway development because of lack of transport capacity. At present, with the rapid development of our national economy, the huge passenger and freight transport needs of the whole society broke out with pressure to the railway.The railway transportation capacity and the contradiction are prominent, due to the shortage of railway transport capacity consequences more sweeping. The eastern part of the railway is more developed while the central and western regions, especially the western part of the railway is relatively backward, and even some backward areas have not opened rail transportation. This reality will not be conducive to the coordinated development of all regions,but also the healthy development of the national economy will have a negative impact.

\subsection{The specific functions of the transport sector are not clear}

At present in our country railway enterprise management system, the railway transportation industry is in the market economic system. What is the pure public welfare industry or the market main body is not clear. That this attribute is unknown is a direct result of people to the railway transportation industry as the enterprise, and the government should also be financial subsidies. It is this long-term nature that is unknown, resulting in the lack of competitive ability in the rail transportation industry and the loss of enthusiasm and motivation can reduce costs and create profits. At present, despite the constant reform of state-owned enterprises, the Ministry of Railways has delegated many management rights and other related rights to the railway transport enterprises.This is only nominal decentralization. Railway transportation enterprises are far from being market players.

\subsection{Internal railway system lack of competition mechanism and the service quality is not high}

China's railway transportation industry carried out the restructuring of the modern enterprise system.Because of the lack of correct guidance and reform, it spent a great deal of reform cost and achieved little success. The monopoly of state-owned capital of enterprises has not changed fundamentally. The relatively independent management system has not yet been established, and it still belongs to monopoly state-owned enterprises. In the face of market competition.it is becoming increasingly fierce, and blind unresponsive is one of the main causes of decline of railway transportation efficiency.

\subsection{Safety management station along the railway exists management lags behind other issues}

The station along the railway security plays a very important role in the safety of railway transportation.Railway transportation industry itself not only affects the production efficiency and economic benefits,it but also has great influence on the social politics and economy.There are 
management and "passive punishment escrow" phenomenon. Stations can punish relevant personnel for a variety of security business guidance and education. The effect of this kind of "independent escrow" can only temporarily alleviate the severe railway transportation safety faced by the small stations along the way, but the consequence is the psychological resistance produced by railway employees. This kind of lagging security management mode is lack of stability and continuity, and it will greatly weaken the foundation of railway transportation safety.

\subsection{The railway transportation industry is facing cost pressures}

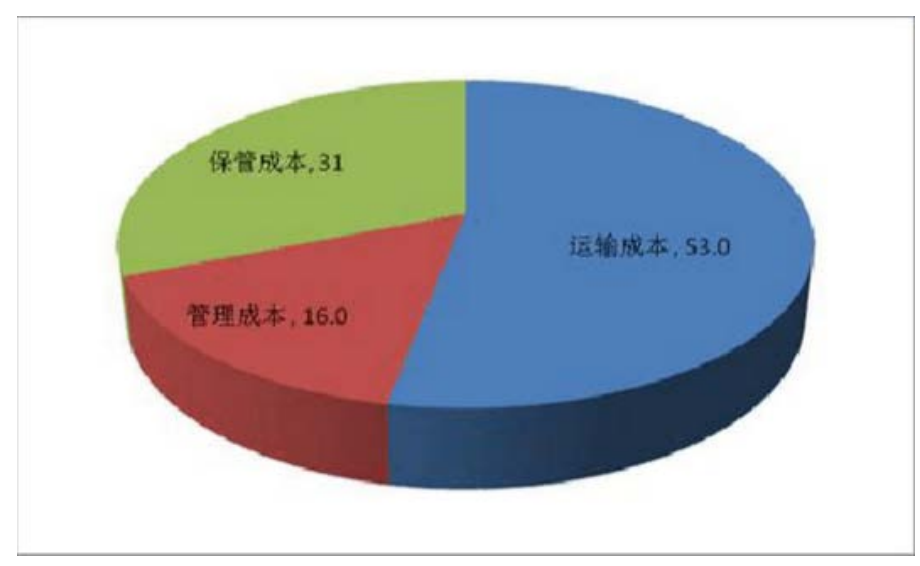

Fig 1 It focuses on the logistics cost of enterprises (unit:\%)

At present, the railway transportation industry is facing cost pressures(As shown in Fig 1), such as the Guangzhou and Shenzhen railway announced before the date of the report shows that labor costs increased by $21.90 \%$. In addition, the Ministry of Railways faces greater financing and profitability pressures according to past years experience.Before April 1st,the railway freight rates had a window up. According to the previous history of railway freight, in the year of 1998, 2003, 2005 and 2009 respectively increased 19.6\%, railway freight were significantly higher than the other price year.

\section{Countermeasures of modern enterprise transport of goods}

\subsection{Speed up road construction and improve railway transport capacity}

From a national perspective, some areas of the eastern railway capacity is relatively loose.These problems do not exist basically.But ten years ago, this problem also existed in the East,and there were a variety of such charges.Now, the railway transportation is not nervous,and this is no charge. The second is to improve the degree of organization,and the ability of Chinese railway transport organization is to transport the highest potency in the world.It is also the largest, but also it can further improve the space.If you do some adjustments and improvements in the organization,it will have more capacity to meet the needs, which is a fundamental solution to this problem.

\subsection{To solve the problem of transport capacity and transparency}

The key to this problem is in charge of the standard, including charges for these rules should be open and transparent so that consumers can know.For example, in the winter, when coal is relatively tight, the price may be slightly higher than in summer.It must be open and transparent, and it also includes various companies including some procedures such as the following fees, agency fees and so on. These must be open to the public,then let the consumer to be able to understand according to their own needs. 


\subsection{Transportation business and secondary separation}

According to statistics by the end of 2005,the number of the Ministry of railways in our China railway rasied to 2 million 284 thousand,which transportation staff is huge, and this is the rest of the world without the phenomenon of railway industry. The railway management society will be large and complete, and it will inevitably restrict the development of railway transportation industry. The public sector in the railway system should be stripped out of the railway system such as public security, hospitals and schools and other social institutions. These units can be said to have no direct relationship with the railway transportation,and the term "bundled" will cause the transportationbusiness professional advantage which is not prominent.The competition ability is low.

In addition, the auxiliary industries in the railway system should be stripped, namely industry, construction, engineering, communications and materials, the five major companies and a number of survey and design institutes, as well as the railway communication network coexisting with the State Post and telecommunications network. The depot and other transportation business in the public works section "diversified" should also be deleted. The department or the industry though and railway transportation industrial property can easily lead to unclear responsibilities, passing the selection committee.

\subsection{The railway transport industry standard joint-stock}

Stock system is the form of assets organization which has been proved to be effective in the past more than 100 years. It can not only rapidly collect social capital, but also improve the corporate governance structure. In the railway industry under the premise of complete separation of main and auxiliary,it can choose the high quality assets with the main line, passenger line and intercity passenger rail projects.For domestic and foreign investors, joint-stock enterprises can realize the sustained and rapid development.

\subsection{Raise construction fund active in a variety of ways}

In our country, the key problem that restricts the development of railway transportation is the problem of fund. The United States has been able to railway construction in the year 1887, laying more than 20 thousand kilometers. One of the important reasons is that has developed the perfect capital market, which can rapidly absorb domestic and foreign investment funds. Although the capital market of our country is not developed, it has the advantage of absorbing the investment.We can see the figure below for specific data as fig 2 .

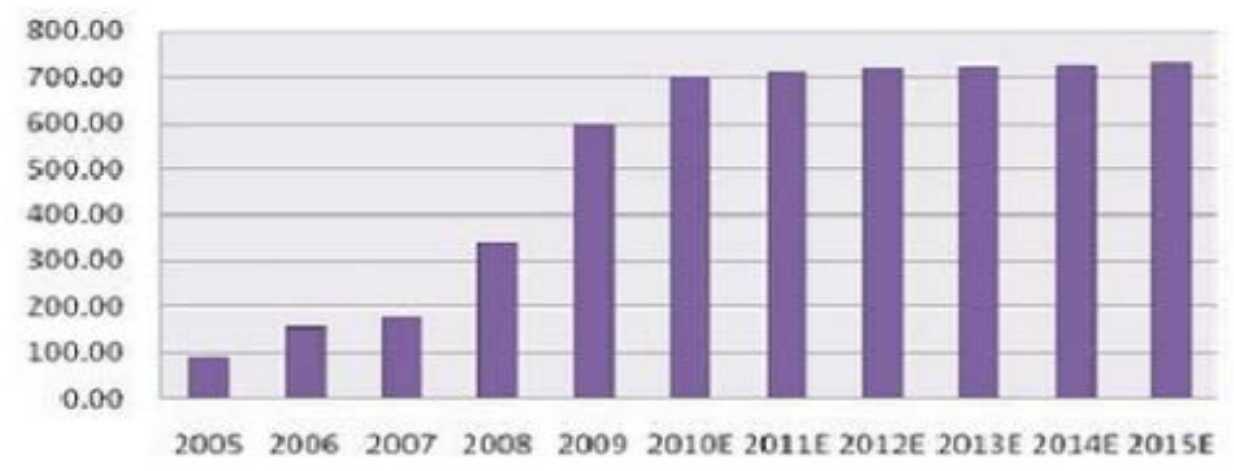

Fig 2 China Railway Infrastructure Investment

\section{Conclusion}

The development strategy of railway transportation industry is not only a serious practice 
problem, but also an important theoretical subject. By comparing China railway construction and development of the historical review and analysis of foreign railway industry, it is easy to conclude the railway transportation industry weak material basis.Now,we can found that there is a shortage of capacity. And only these are far from enough, the key question is: how to achieve their own development strategy to determine in the rapid progress of technology, fierce industry era railway transportation industry. The research on the development strategy of railway transportation industry is a subject of great intension, policy and practice. Because of the limitation of length and the author's knowledge level, the outline of the railway transport industry's development strategy for the overall outline and description are far from in-depth, detailed and comprehensive.In this paper, the shortcomings and defects can hardly be avoided.

\section{References}

[1] Leech, Geoffrey.Matters needing attention in freight transportation[M]. London: Longman Group Ltd, 2013.

[2] Linell, Davis. The existing problems of freight transportation in modern enterprises[M]. Beijing: Foreign language Teaching and Research Press, 2011.

[3] Neaman, Judith S. and Carole G. Silver. How important is the transportation of goods in an enterprise?[M]. New York: Facts On File, Inc., 2010.

[4] Peng, Xiaochun. Freight transportation[D]. South China Normal University, 2013.

[5] H Holec, Matters needing attention in freight transportation (Oxford: Pergamum Press, 2011), 22.

[6] Yang Fei. How to solve the problem of goods transportation?[J]. Foreign Language School of Shandong Normal University. 2011 (05) 